\title{
Genetic Diversity and Differentiation in Phoma betae Populations on Table Beet in New York and Washington States
}

\author{
Lori B. Koenick, ${ }^{1}$ Niloofar Vaghefi, ${ }^{2}$ Noel L. Knight, ${ }^{1}$ Lindsey J. du Toit, ${ }^{3}$ and Sarah J. Pethybridge ${ }^{1 \dagger}$ \\ ${ }^{1}$ Plant Pathology and Plant-Microbe Biology Section, School of Integrative Plant Science, Cornell AgriTech at the New York \\ State Agricultural Experiment Station, Cornell University, Geneva, NY 14456, U.S.A.; ${ }^{2}$ Centre for Crop Health, University of \\ Southern Queensland, Toowoomba, Queensland 4350, Australia; and ${ }^{3}$ Washington State University, Mount Vernon Northwest- \\ ern Washington Research and Extension Center, Mount Vernon, WA 98273, U.S.A.
}

\begin{abstract}
Phoma betae is an important seedborne pathogen of table beet worldwide that is capable of causing foliar, root, and damping-off diseases. Ten microsatellite and mating type markers were developed to investigate the genetics of $P$. betae populations in table beet root crops in New York and in table beet seed crops in Washington, from where table beet seed is predominantly sourced. The markers were used to characterize 175 isolates comprising five $P$. betae populations (two from New York and three from Washington), and they were highly polymorphic with an allelic range of 4 to 33 and an average of 11.7 alleles per locus. All populations had high genotypic diversity (Simpson's complement index $=0.857$ to 0.924 ) and moderate allelic diversity (Nei's unbiased gene diversity = 0.582 to 0.653$)$. Greater differentiation observed between populations

from the two states compared with populations within the same state suggested that an external inoculum source, such as windblown ascospores, may be homogenizing the populations. However, most genetic diversity $(87 \%)$ was among individual isolates within populations (pairwise index of population differentiation $=0.127 ; P=0.001$ ), suggesting that local within-field inoculum source(s), such as infested field debris or infected weeds, may also be important in initiating disease outbreaks. Standardized index of association, proportion of compatible pairs of loci, and mating type ratio calculations showed evidence for a mixed reproduction mode in all populations. These findings could be useful in designing more effective management strategies for diseases caused by $P$. betae in table beet production.
\end{abstract}

The U.S. table beet (Beta vulgaris L. subsp. vulgaris) industry currently supplies approximately 116,000 tons of table beets for processing and fresh markets annually (USDA-NASS 2012). New York is the second largest producer of table beets in the United States, producing around 30,000 tons annually (USDA-NASS 2012). In New York, table beets are grown using conventional and organic production practices in a broad range of farming systems from small, mixed crop farms to broad acre, monoculture fields (Pethybridge et al. 2017, 2018; Stivers 2001). Seed used to establish table beet fields for processing in New York is predominantly produced in the maritime Pacific Northwest region of the United States (western Washington and western Oregon) and New Zealand (du Toit 2007). Seed used to establish fields in smaller-scale, conventional, and organic production

${ }^{\dagger}$ Corresponding author: S. J. Pethybridge; sjp277@cornell.edu

Funding: This research was supported by the U.S. Department of Agriculture National Institute of Food and Agriculture Hatch Project NYG-625-424, managed by the New York State Agricultural Experiment Station (NYSAES) at Cornell University. The Endowment Fund controlled by the NYSAES director also contributed to the microsatellite development. Funding for the Washington component of this study was provided by the Puget Sound Seed Growers' Association via the Northwest Agricultural Research Foundation, the Washington State Commission for Pesticide Registration, the Alfred Christianson Endowment, and the Washington State University Department of Plant Pathology, College of Agricultural, Human, and Natural Resource Sciences, Agricultural Research Center Hatch Project Numbers WPN00595 and WPN05595. L. B. Koenick was supported in part by a fellowship from the Cornell Graduate School.

*The $\boldsymbol{e}$-Xtra logo stands for "electronic extra" and indicates that five supplementary figures and two supplementary tables are published online.

The author(s) declare no conflict of interest.

Accepted for publication 20 December 2018.

@ 2019 The American Phytopathological Society typically is sourced from a range of merchants based in the United States (J. Kikkert, personal communication).

Phoma betae (syn. Neocamarosporium betae) (Ariyawansa et al. 2015 ) is an important pathogen of table beet, sugar beet, and Swiss chard worldwide and can negatively affect crop stands by causing damping-off (Edson 1915) and/or reducing the photosynthetic leaf area as a result of Phoma leaf spot (Edson 1915; Leach and MacDonald 1976; Pool and McKay 1915). On leaves, P. betae causes large, circular, tan-colored leaf spots, which can coalesce rapidly to cause defoliation (Harveson et al. 2009; Pethybridge et al. 2018; Pool and McKay 1915). The pathogen also reduces root quality, such that infected roots decay in storage (Abawi et al. 1986; Bugbee 1982; Bugbee and Cole 1981; Edson 1915; Pethybridge et al. 2018). On roots, rot typically starts in the center of the crown and spreads into the taproot (Bugbee 1982; Edson 1915), appearing as dark-brown, dry lesions that can lead to shrinkage (Edson 1915; Harveson et al. 2009). The pathogen also infects roots through wounds. In New York and Washington, the prevalence of foliar and root diseases caused by $P$. betae varies with growing conditions. In New York, surveys have shown Phoma leaf spot to be present predominantly in fields grown with organic production practices (L. B. Koenick and S. J. Pethybridge, unpublished data). In 2017, Phoma leaf spot was found in $73 \%$ of table beet root fields in New York grown with organic production practices $(n=11)$ and $71 \%$ of conventional fields $(n=17)$ (L. B. Koenick and S. J. Pethybridge, unpublished data). In 2016, Phoma leaf spot was found in $25 \%$ of table beet seed crop fields surveyed in Washington $(n=11)$ (du Toit 2017).

P. betae is a haploid ascomycete (Aveskamp et al. 2009, 2010; de Gruyter et al. 2013), capable of asexual and sexual reproduction. Asexual reproduction contributes to the rapid spread of the disease through polycyclic epidemics resulting from rain or irrigation splash of conidia produced by pycnidia on diseased plant material (Harveson et al. 2009; Leach and MacDonald 1976; Monte and García-Acha 1988), whereas sexually produced ascospores released from pseudothecia promote longer distance, aerial dispersal (Bugbee 1979). P. betae therefore has multiple modes of initiating epidemics each season (Bugbee 1982; Harveson et al. 2009). Ascospores may be transported by wind currents and hence may initiate infections 
across multiple fields in a region (Bugbee 1979). P. betae may also be seedborne; therefore, infected seeds can be an important pathway for the introduction of inoculum and initiation of epidemics (Edson 1915; Herr 1971; Leach and MacDonald 1976; Mangan 1971). Seed treatments, such as thiram and hot water, are effective management practices for limiting the potential for seedborne inoculum to initiate infections in beet crops (Maude et al. 1969). The pathogen can also survive on infested plant debris between growing seasons. In the Red River Valley of North Dakota and Minnesota, Bugbee and Soine (1974) reported that $P$. betae could survive up to 26 months in the soil on infested sugar beet plant debris, and that $P$. betae was not found in fields after 3 years of rotation to nonhost crops. Infected weeds can also serve as an inoculum source between growing seasons. $P$. betae has been reported to infect the roots of Chenopodium album (lambsquarters) in fields and sugar beet storage yards (Bugbee and Soine 1974). Most information on the biology of $P$. betae has resulted from studies conducted on sugar beet, also classified as B. vulgaris. Sugar beets are cultivated using similar production practices to table beet, yet they are grown predominantly for the production of sucrose (Harveson et al. 2009). P. betae is of increasing importance to New York table beet production because of the increase in organic production, which negates the use of thiram as a seed treatment (Maude et al. 1969). Limited literature is available on the relative importance of different sources of $P$. betae inoculum initiating epidemics in New York table beet production.

Knowledge of the genetic diversity, differentiation, and reproductive biology of pathogen populations supports the design of durable strategies and tactics for disease management. Population biology is the interdisciplinary subject combining population genetic and epidemiological concepts to study the ecological and evolutionary dynamics of plants and plant pathogens at the population level (Milgroom 2001). Population biology studies can provide indirect evidence to test hypotheses regarding pathogen biology and epidemiology (McDonald 2015; McDonald and Mundt 2016). Milgroom (2015) defined population genetics as the study of evolutionary processes (mutation, selection, recombination, random genetic drift, and migration) that generate and maintain genetic variation within and among populations. These studies use patterns of allele frequencies as genetic evidence to derive information about the evolutionary processes shaping populations (Carbone and Kohn 2004; Grünwald et al. 2017). Information from population biology studies has been used to evaluate the relative contribution of inoculum sources for some pathogens such as Phaeosphaeria nodorum on winter wheat (Bennett et al. 2007) and Rhizoctonia solani on potato (Muzhinji et al. 2018). For example, if primary inoculum is dominant from a source external to the field of interest, such as infected seed or windblown ascospores, low population differentiation among fields is expected. If primary inoculum is arising from within fields, such as infested overwintering plant debris or weedy host reservoirs, high population differentiation among fields is predicted ( $\mathrm{Li}$ and Brewer 2016). Population biology studies have also been used to test hypotheses regarding pathogen origin (Goss et al. 2014), migration pathways (Banke and McDonald 2005; Estoup and Guillemaud 2010), patterns of emergence and reemergence (Grünwald and Goss 2011; Grünwald et al. 2012), and reproductive biology (Milgroom et al. 2014; Short et al. 2014; Vaghefi et al. 2017b). To our knowledge, information on the population biology of $P$. betae currently is not available.

Investigating the structure and evolutionary history of populations requires selectively neutral genetic markers (Grünwald et al. 2017). Microsatellites or simple sequence repeats (SSRs) are a popular choice for population biology studies, owing to their high degree of polymorphism, reproducibility, locus specificity, abundance, and neutrality (Bruford and Wayne 1993; Ellegren 2004). In combination, microsatellites and mating type markers can be used to investigate pathogen reproductive strategy, which can have considerable implications on population structure, disease inoculum sources, and management strategies (McDonald and Linde 2002; Milgroom 1996).

Asexual (clonal) reproduction produces genomes identical to the parent genome and allows for swift dispersal of successful genotypes (Milgroom 1996; Taylor et al. 1999). In contrast, sexual reproduction involves recombination in eukaryotic organisms. Recombination facilitates the exchange of genetic material among organisms and hence contributes to the rapid formation of novel multilocus genotypes (MLGs) and the purging of deleterious mutations from populations (Milgroom 1996, 2015). The mating type (MAT1) locus controls sexual reproduction in ascomycetes (Coppin et al. 1997; Debuchy and Turgeon 2006). The MAT1 locus in most ascomycetes carries either one or two mating type alleles (MAT1-1 and MAT1-2), both of which are usually required for sexual reproduction (Coppin et al. 1997). The MAT1-1 and MAT1-2 open reading frames (ORFs) encode proteins with an alpha box domain and a DNA-binding domain of a high mobility group (HMG) type, respectively (Debuchy and Turgeon 2006). Based on the structure of the mating type locus, ascomycetes are classified as heterothallic (self-incompatible) or homothallic (self-compatible). For heterothallic fungi, two isolates carrying alternate mating types are required for sexual reproduction. Therefore, an equal ratio of MAT1-1 and MAT1-2 isolates in populations can provide evidence for random mating (Milgroom 2015; Zhan et al. 2002). The mating type locus has not been characterized for $P$. betae and the sexual form of $P$. betae has not been observed in New York (S. J. Pethybridge, unpublished data).

The objectives of this study were to develop a reproducible and polymorphic microsatellite library for $P$. betae, characterize the MAT1 locus for $P$. betae, and use both microsatellite and mating type genetic markers to examine the diversity, differentiation, and reproductive strategy of $P$. betae populations in table beet fields grown for seed in Washington and roots in New York. Microsatellites were selected to facilitate relatively rapid and cost-effective screening of diversity within P. betae populations (Milgroom 2015).

\section{Materials and Methods}

Fungal isolate sampling strategy and DNA extraction. A total of 198 P. betae isolates were used in this study. Twenty-three isolates collected from table beet were used for microsatellite library development (Table 1). These included isolates from New York and Washington and three reference strains from international culture collections.

Table 1. Geographical location and date of collection of Phoma betae isolates from Washington and New York states, and culture collections used for microsatellite library development for this study

\begin{tabular}{llc}
\hline Isolate $^{\mathbf{a}}$ & \multicolumn{1}{c}{ Location } & Date \\
\hline CBS 109410= PD 77/113 & The Netherlands & - \\
ICMP 10945 & New Zealand & 1979 \\
$\mathrm{IMI} 156653$ & Warwickshire, England & 1968 \\
$\mathrm{~Pb} 1$ & New York & 2014 \\
$\mathrm{~Pb} 2$ & Cayuga County, NY & 2015 \\
$\mathrm{Pb3}$ & Cayuga County, NY & 2015 \\
$\mathrm{~Pb} 4$ & Cayuga County, NY & 2015 \\
$\mathrm{Pb7}$ & Batavia, Genesee County, NY & 2015 \\
$\mathrm{Pb8}$ & Batavia, Genesee County, NY & 2015 \\
$\mathrm{Pb9}$ & Batavia, Genesee County, NY & 2015 \\
$\mathrm{~Pb} 12$ & Batavia, Genesee County, NY & 2015 \\
$\mathrm{Phb03}$ & Whidbey Island, Island County, WA & 2014 \\
$\mathrm{Phb05}$ & Whidbey Island, Island County, WA & 2014 \\
$\mathrm{Phb10}$ & Whidbey Island, Island County, WA & 2014 \\
$\mathrm{Phb11}$ & Skagit County, WA & 2014 \\
$\mathrm{Phb14}$ & Skagit County, WA & 2015 \\
$\mathrm{Phb16}$ & Skagit County, WA & 2015 \\
$\mathrm{Phb18}$ & Skagit County, WA & 2015 \\
$\mathrm{Phb20}$ & Skagit County, WA & 2015 \\
$\mathrm{Phb22}$ & Skagit County, WA & 2015 \\
$\mathrm{Phb30}$ & Whidbey Island, Island County, WA & 2015 \\
$\mathrm{Phb39}$ & Stanwood, Skagit County, WA & 2016 \\
$\mathrm{Phb40}$ & Stanwood, Skagit County, WA & 2016 \\
\hline $\mathrm{Al}$ & &
\end{tabular}

a All nonreference isolates are from table beet. Reference strains were obtained from international culture collections. The host of CBS $109410=$ PD 77/113 is listed as Beta vulgaris and date of collection is not listed. ICMP 10945 was sourced from a root lesion on B. vulgaris. IMI 156653 was sourced from seed of $B$. vulgaris. 
A total of $175 P$. betae isolates was used for genotyping populations from New York and Washington (70 from New York and 105 from Washington). Two populations of 35 P. betae isolates each were collected from table beet root fields in New York (NY1 and NY2) in 2017. Population NY1 was collected in a field (cultivar Ruby Queen) in Ontario County and population NY2 was collected in a field (cultivar Red Ace) in Essex County. Three populations of 35 P. betae isolates each were collected from table beet seed fields (proprietary identity of cultivars) in western Washington (WA1, WA2, and WA3) in 2016 in Skagit County. The term "population" is used in this study to refer to a group of isolates collected from the same table beet field.

In each population, each isolate originated from a single Phoma leaf spot lesion, and all isolates in that population originated from different leaves in the same table beet field. Isolates collected in New York were obtained by removing three pycnidia, followed by placement into $200 \mu \mathrm{l}$ of sterile water in the same $1.5-\mathrm{ml}$ tube. The tube was vortexed vigorously and $100 \mu l$ of the conidial suspension was spread on $2 \%$ water agar (Hardy Diagnostics, Santa Maria, CA) amended with $0.02 \%(w / v)$ ampicillin (Sigma-Aldrich, St. Louis, MO) and $0.02 \%$ (w/v) streptomycin (Sigma-Aldrich). After $24 \mathrm{~h}$, germinated conidia were excised and placed on clarified V8 (CV8) juice [10\% (v/v) CV8 juice (Campbell's Soup Co., Camden, $\mathrm{NJ}), 0.5 \%(\mathrm{w} / \mathrm{v}) \mathrm{CaCO}_{3}$ ] agar (Jeffers 2015; Miller 1955). Isolates collected from seed crops in western Washington were each obtained by surface sterilizing a piece of symptomatic leaf material in $95 \%$ ethyl alcohol, drying the tissue thoroughly, and plating half of each lesion onto $2 \%$ water agar and the other half onto half-strength potato dextrose agar. Fungal isolates with morphological characteristics resembling $P$. betae (mycelial color and growth characteristics, pycnidia production, and presence of holdfasts at the interface of the $2 \%$ water agar and surface of the Petri plate; International Seed Testing Association 1982) were streaked onto new plates of $2 \%$ water agar to obtain single-conidium isolates.

For DNA extraction, single-conidium isolates were grown in CV8 broth [10\% (v/v) CV8 juice] for 4 to 7 days. Genomic DNA was extracted using the Wizard Genomic DNA Purification Kit (Promega, Madison, WI) following the manufacturer's instructions. For each isolate, 50 to $120 \mathrm{mg}$ of wet mycelium was ground in Nuclei Lysis Solution in a 2-ml microcentrifuge tube with two 4.5-mm diameter, zinc-plated, spherical balls (Daisy premium grade BBs; Daisy, Rogers, AR) using a tissue homogenizer (TissueLyser; QIAGEN, Valencia, CA). The quantity of extracted DNA was determined using a NanoDrop ND-1000 spectrophotometer (NanoDrop Technologies, Wilmington, DE). The quality of the DNA samples was evaluated through gel electrophoresis on a $1 \%(\mathrm{w} / \mathrm{v})$ agarose gel in Trisacetate-ethylenediaminetetraacetic acid (EDTA) amended with $0.001 \%$ (v/v) GelRed (Biotium Inc., Hayward, CA). Product size was determined against a 100-bp DNA ladder (Axygen Inc., Union City, CA).

Microsatellite marker development. Microsatellite marker development followed the general protocol used for Cercospora beticola by Vaghefi et al. (2017a). A de novo genome assembly for isolate $\mathrm{Pb} 1(\mathrm{~N}$. Vaghefi and S. J. Pethybridge, unpublished data) was used as the scaffold for identification of microsatellite motifs in Tandem Repeat Finder version 408 (Benson 1999). The search was restricted to sequences with tri- to hexa-nucleotide repeat motifs, with a minimum score of 50, a matching point of two, and a copy number of at least five. Forty loci were selected initially for primer design. To minimize the probability of physical linkage of loci, only one microsatellite per contig was selected for primer design. Moreover, the genome within $5 \mathrm{~kb}$ of the microsatellite motifs was searched in the Basic Local Alignment Search Tool (BLAST) against the National Center for Biotechnology Information nuclear ribosomal DNA database in GenBank to ensure that loci were not linked to genic regions. Microsatellite primers for each of the 40 motifs were designed using the program Primer3 version 0.4.0 (Untergasser et al. 2012), with melting temperatures between 58 and $60^{\circ} \mathrm{C}$ and product sizes ranging from 90 to $450 \mathrm{bp}$ to allow for multiplexing. Each primer pair was tested initially using a subset of eight $P$. betae isolates with a polymerase chain reaction (PCR) assay. The assay was conducted in a total volume of $15 \mu$ l and contained $1 \times$ Standard PCR buffer (New England Biolabs Inc., Ipswich, MA), $1.5 \mathrm{mM}$ of $\mathrm{MgCl}_{2}$ (New England Biolabs), $0.1 \mathrm{mM}$ of dNTPs (New England Biolabs), $0.1 \mu \mathrm{M}$ of each primer (Integrated DNA Technologies, Skokie, IL), $0.8 \mathrm{U}$ of Taq polymerase (New England Biolabs), and 8 to $10 \mathrm{ng}$ of template DNA. The PCR conditions included an initial denaturation for $10 \mathrm{~min}$ at $95^{\circ} \mathrm{C}$; followed by 34 cycles of denaturation at $95^{\circ} \mathrm{C}$ for $30 \mathrm{~s}$, annealing at $58^{\circ} \mathrm{C}$ for $20 \mathrm{~s}$, and extension at $68^{\circ} \mathrm{C}$ for $30 \mathrm{~s}$; and a final extension at $68^{\circ} \mathrm{C}$ for $5 \mathrm{~min}$. Ten primer pairs were selected for evaluation based on amplification of single bands of expected size for all isolates visualized on a $1 \%$ agarose gel containing $0.001 \%(\mathrm{v} / \mathrm{v})$ GelRed.

Microsatellite evaluation for polymorphism and multiplexing. The $5^{\prime}$ end of the forward primer for each of the markers was labeled with one of four fluorophores (6-FAM, NED, PET, and VIC; Applied Biosystems, Foster City, CA) to allow for multiplexing. PCR assays were performed on $23 P$. betae isolates (Table 1) as described above with an annealing temperature of $58^{\circ} \mathrm{C}$. Fragment analysis of the fluorescently labeled PCR products was done on an ABI 3730xl DNA Analyzer at the Biotechnology Resource Center (Institute of Biotechnology, Cornell University, Ithaca, NY) with a GeneScan-600 LIZ size standard (Applied Biosystems). Alleles were scored using Microsatellite Plugin version 1.4 in Geneious version 9.1.5 (https:// www.geneious.com; Kearse et al. 2012). All 10 loci were polymorphic, operationally defined as resulting in at least two alleles, and had a minor allele frequency of at least 0.01 . PCR assays and fragment analysis were repeated on all $23 P$. betae isolates to evaluate reproducibility and estimate error rates for all loci (Pompanon et al. 2005). Summary statistics for each locus were calculated in GenAlEx version 6.503 (Peakall and Smouse 2006, 2012) and in the R (R Core Team 2017) package poppr version 2.6.1 (Kamvar et al. 2014, 2015) (Table 2). PCR products of the 10 markers from four $P$. betae isolates (Pb1, Pb2, Phb18, and Phb22) were sequenced using an Applied Biosystems Automated 3730xl DNA Analyzer at the Biotechnology Resource Center (Institute of Biotechnology, Cornell University) to ensure that they contained the target repeat motif.

Multiplex Manager version 1.2 software (Holleley and Geerts 2009) assigned the 10 polymorphic markers into two multiplex PCR sets, containing six and four markers, respectively (Supplementary Table S1), with a minimum distance between the loci of $50 \mathrm{bp}$ and a complementary threshold of seven. Multiplex PCR assays were each performed in a $25 \mu \mathrm{l}$ volume consisting of 8 to $10 \mathrm{ng}$ of template DNA, $1 \times$ of the Multiplex PCR $5 \times$ Master Mix (New England BioLabs), and 0.1 $\mu \mathrm{M}$ of primers. Multiplex PCR assay conditions included an initial denaturation for $2 \mathrm{~min}$ at $95^{\circ} \mathrm{C}$; followed by 35 cycles of denaturation at $95^{\circ} \mathrm{C}$ for $30 \mathrm{~s}$, annealing at $58^{\circ} \mathrm{C}$ for $30 \mathrm{~s}$, and extension at $68^{\circ} \mathrm{C}$ for $2 \mathrm{~min}$; and a final extension at $68^{\circ} \mathrm{C}$ for $5 \mathrm{~min}$. Reproducibility of this assay was evaluated by conducting repeat PCR assays and fragment analysis on the same isolates used for marker development. Markers were evaluated for their ability to describe genetic variability of $175 P$. betae isolates adequately by inspection of a genotype accumulation curve using poppr.

Mating type gene discovery and amplification. The genome assembly of $P$. betae was used to create a BLAST database in Geneious. Sequences of MAT1-1-1 (GenBank accession AB009451) and MAT1-2-1 from Alternaria alternata (GenBank accession AB005039) were retrieved from the GenBank nucleotide database (Clark et al. 2016) and used in queries against the $P$. betae genome to identify potential orthologs. The identified contig from the $P$. betae genome was analyzed in FGENESH+ (Solovyev 2007) using the sequence of the homologous protein from Stemphylium vesicarium (GenBank accession AAR00940) to find putative ORFs and intron splicing sites.

Only one mating type (MAT1-2-1) was detected in the genome of isolate $\mathrm{Pb} 1$. Therefore, primers specific to the MAT1-2-1 ORF ( $\mathrm{Pb}$ MAT2-F and Pb-MAT2-R; Table 3) were designed using Primer3 to evaluate the five populations of $P$. betae from New York and Washington. Individual isolates from which the expected PCR product was not obtained were identified as putative MAT1-1 isolates. 
PCR assays were each conducted in a total volume of $25 \mu l$ and contained $1 \times$ Standard PCR buffer, $1.5 \mathrm{mM}$ of $\mathrm{MgCl}_{2}, 0.1 \mathrm{mM}$ of dNTPs, $0.1 \mu \mathrm{M}$ of each primer, $0.8 \mathrm{U}$ of Taq polymerase, and 8 to 10 ng of template DNA. The PCR assays included an initial denaturation for $5 \mathrm{~min}$ at $95^{\circ} \mathrm{C}$; followed by 35 cycles of denaturation at $95^{\circ} \mathrm{C}$ for $30 \mathrm{~s}$, annealing at $55^{\circ} \mathrm{C}$ for $30 \mathrm{~s}$, and extension at $68^{\circ} \mathrm{C}$ for $30 \mathrm{~s}$; and a final extension at $68^{\circ} \mathrm{C}$ for $5 \mathrm{~min}$.

Additional primers were designed for amplification of the entire MAT1 locus in putative MAT1-1 isolates (Table 3). First, to identify the flanking region of the MAT1 locus where MAT1-1 and MAT1-2 alleles showed high similarity, the MAT1-2 locus of $P$. betae was aligned with the MAT1-1 and MAT1-2 sequences of Ulocladium botrytis (GenBank accessions KF533878 and KF533888) using the MAFFT plugin in Geneious. The selection of $U$. botrytis as a template was based on this fungus belonging to the Pleosporaceae and public availability of the entire MAT1 loci and flanking regions. Primers were designed in the flanking regions to amplify the MAT1 locus in MAT1-2 and putative MAT1-1 isolates (Table 3). Primers

Table 2. Characteristics of microsatellite markers developed for Phoma betae based on 198 isolates from New York and Washington States (23 isolates for development of the markers and 175 isolates for genotyping)

\begin{tabular}{|c|c|c|c|c|c|c|}
\hline $\begin{array}{l}\text { Microsatellite } \\
\text { locus }\end{array}$ & $\begin{array}{c}\text { Scaffold } \\
\text { length }^{\mathbf{a}}(\mathbf{b p})\end{array}$ & $\begin{array}{l}\text { Repeat } \\
\text { motif }^{b}\end{array}$ & Primer pair ${ }^{\mathrm{c}}\left(5^{\prime}-3^{\prime}\right)$ & $\mathbf{N}^{\mathbf{d}}$ & $\mathbf{H}^{\mathbf{e}}$ & $\begin{array}{c}\text { Accession } \\
\text { number }^{f}\end{array}$ \\
\hline PbSSR0 & $2,201,606$ & $(\mathrm{AGT})_{34}$ & $\begin{array}{l}\text { F: AAATGGGCGGAACACACTAC } \\
\text { R: TATTTTGCGCATAGGGAAGG }\end{array}$ & 33 & 0.92 & $\begin{array}{l}\text { MH823546 } \\
\text { MH823556 } \\
\text { MH823566 } \\
\text { MH823576 }\end{array}$ \\
\hline PbSSR4 & $1,413,381$ & $(\mathrm{GTT})_{18}$ & $\begin{array}{l}\text { F: GCAGTCGTCAGCGTCAATTA } \\
\text { R: CCGGCACTATCACGTCTTCT }\end{array}$ & 19 & 0.84 & $\begin{array}{l}\text { MH823547 } \\
\text { MH823557 } \\
\text { MH823567 } \\
\text { MH823577 }\end{array}$ \\
\hline PbSSR8 & $1,307,838$ & $(\mathrm{GAA})_{24}$ & $\begin{array}{l}\text { F: CTGGGATTTTGAGGACGAGA } \\
\text { R: CATCCTGCAATATGCCCTTT }\end{array}$ & 10 & 0.68 & $\begin{array}{l}\text { MH823548 } \\
\text { MH823558 } \\
\text { MH823568 } \\
\text { MH823578 }\end{array}$ \\
\hline PbSSR24 & 849,996 & $(\mathrm{CAA})_{13}$ & $\begin{array}{l}\text { F: CAGCGTCACAAGTTCCTTCA } \\
\text { R: CCTGTTTGCGTTGACAGAGA }\end{array}$ & 12 & 0.71 & $\begin{array}{l}\text { MH823549 } \\
\text { MH823559 } \\
\text { MH823569 } \\
\text { MH823579 }\end{array}$ \\
\hline PbSSR34 & 746,462 & $(\text { CTTTCA })_{9}$ & $\begin{array}{l}\text { F: CGTTCCCGGATACAAACTGT } \\
\text { R: } \\
\text { GATGAGCGGAATAAGGACGA }\end{array}$ & 7 & 0.62 & $\begin{array}{l}\text { MH823550 } \\
\text { MH823560 } \\
\text { MH823570 } \\
\text { MH823580 }\end{array}$ \\
\hline PbSSR36 & 713,435 & $(\mathrm{AAC})_{14}$ & $\begin{array}{l}\text { F: CGCTGGTGAGAAACATCAGA } \\
\text { R: CCATTTTGTGTGTGGTGGAG }\end{array}$ & 11 & 0.76 & $\begin{array}{l}\text { MH823551 } \\
\text { MH823561 } \\
\text { MH823571 } \\
\text { MH823581 }\end{array}$ \\
\hline PbSSR52 & 483,740 & $(\mathrm{GAA})_{11}$ & $\begin{array}{l}\text { F: GAGCCAACTCAGACGAAACC } \\
\text { R: ACCCTGGCATTTATTCATCG }\end{array}$ & 9 & 0.42 & $\begin{array}{l}\text { MH823552 } \\
\text { MH823562 } \\
\text { MH823572 } \\
\text { MH823582 }\end{array}$ \\
\hline PbSSR58 & 445,932 & $(\mathrm{TACA})_{8}$ & $\begin{array}{l}\text { F: GAGTCGACGACAGGCACATA } \\
\text { R: ACCTAACCAATCCGGTAGCC }\end{array}$ & 6 & 0.76 & $\begin{array}{l}\text { MH823553 } \\
\text { MH823563 } \\
\text { MH823573 } \\
\text { MH823583 }\end{array}$ \\
\hline PbSSR78 & 343,640 & $(\mathrm{GGA})_{9}$ & $\begin{array}{l}\text { F: TCAGGATGTGGAGAGGTTCC } \\
\text { R: CAATCCCCTCCTCATGACAC }\end{array}$ & 4 & 0.55 & $\begin{array}{l}\text { MH823554 } \\
\text { MH823564 } \\
\text { MH823574 } \\
\text { MH823584 }\end{array}$ \\
\hline PbSSR80 & 339,604 & $(\mathrm{GAA})_{11}$ & $\begin{array}{l}\text { F: GACACACTCGCCAAAGTCCT } \\
\text { R: TCAAACTCTGCTGCACCAAC }\end{array}$ & 6 & 0.71 & $\begin{array}{l}\text { MH823555 } \\
\text { MH823565 } \\
\text { MH823575 } \\
\text { MH823585 }\end{array}$ \\
\hline Total & & & & 11.7 & 0.7 & \\
\hline
\end{tabular}

${ }^{\mathrm{a}}$ Loci were identified in scaffolds from the de novo genome assembly of isolate $\mathrm{Pb} 1$ (N. Vaghefi and $\mathrm{S}$. J. Pethybridge, unpublished data).

${ }^{\mathrm{b}}$ Microsatellite motif is indicated in parentheses and copy number (as found in the genome of $\mathrm{Pb} 1$ ) is listed outside parentheses.

${ }^{\mathrm{c}} \mathrm{F}=$ forward primer, $\mathrm{R}=$ reverse primer

${ }^{\mathrm{d}} \mathrm{N}=$ number of different alleles.

${ }^{\mathrm{e}} \mathrm{H}=$ Nei's $(1978)$ gene diversity $=\left(\frac{N}{N-1}\right) \times\left(1-\sum p^{2}\right)$ where $p$ is the allele frequency at a given locus calculated using poppr (Kamvar et al. 2014, 2015).

${ }^{\mathrm{f}}$ GenBank accession number; each microsatellite locus was sequenced for four isolates of $P$. betae ( $\left.\mathrm{Pb} 1, \mathrm{~Pb} 2, \mathrm{Phb} 18, \mathrm{Phb} 22\right)$.

Table 3. Characteristics of mating type markers developed for Phoma betae ${ }^{\text {a }}$

\begin{tabular}{lllc}
\hline Primer & \multicolumn{1}{c}{ Sequence $\left(5^{\prime}\right.$ to $\mathbf{3}^{\prime}$ ) } & \multicolumn{1}{c}{ Target region } & PCR product size (bp) \\
\hline PbMAT1-F3 & TCTTCAGCATCATATGTCCC & Mating type 1 ORF coding for the conserved alpha box domain & \\
PbMAT1-R3 & TTCGACAGAGAGATTTCCAG & Mating type 2 ORF coding for the conserved HMG domain & 277 \\
PbMAT2-F & TCATCTACCGAGATGCGATG & & \\
PbMAT2-R & CTGGCGCTTCTTCTTCTCTC & MAT1 locus & $\sim 3,800$ \\
PbMAT-F2 & CTCTCTTGGTACACGACTGG & & \\
PbMAT-R3 & GGTGTAAAGCTCGTAAAAGCTAGGTATAG & & \\
\hline
\end{tabular}

${ }^{\mathrm{a}} \mathrm{PCR}=$ polymerase chain reaction, $\mathrm{F}=$ forward primer, $\mathrm{ORF}=$ open reading frame, $\mathrm{R}=$ reverse primer, and $\mathrm{HMG}=$ high mobility group. 
(PbMAT-F2 and PbMAT-R3) were used to amplify an $\sim 3,800$-bp PCR product targeting the MAT1 locus of four P. betae isolates. PCR assays were each conducted in a total volume of $25 \mu l$ and contained 1× Q5 Reaction buffer (New England Biolabs), $200 \mu \mathrm{M}$ of dNTPs, $0.5 \mu \mathrm{M}$ of each primer, $0.02 \mathrm{U} / \mu \mathrm{l}$ of Q5 High-Fidelity DNA polymerase (New England Biolabs), and 8 to $10 \mathrm{ng}$ of template DNA. The PCR conditions included an initial denaturation for $5 \mathrm{~min}$ at $98^{\circ} \mathrm{C}$; followed by 35 cycles of denaturation at $98^{\circ} \mathrm{C}$ for $10 \mathrm{~s}$, annealing at $65^{\circ} \mathrm{C}$ for $30 \mathrm{~s}$, and extension at $72^{\circ} \mathrm{C}$ for $80 \mathrm{~s}$; and a final extension at $72^{\circ} \mathrm{C}$ for $5 \mathrm{~min}$. PCR products of the MAT1 locus were sequenced using the Illumina MiSeq platform at the Center of Computational and Integrative Biology DNA Core Facility at Massachusetts General Hospital (Cambridge, MA).

To identify the MAT1-1 ORF, the MAT1 loci of $P$. betae from MAT1-2 and putative MAT1-1 isolates were aligned with the MAT1-1 sequence of $U$. botrytis (GenBank accession KF533878) and MAT1-1 and MAT1-2 sequences of Stemphylium triglochinicola (GenBank accession AY335167, which includes the sequences of both mating type genes) in Geneious. The MAT1-1 region identified from putative MAT1-1 isolates was analyzed in FGENESH+ using the sequence of the homologous protein from $U$. dauci (GenBank accession AEZ02243) to find the putative ORFs and intron splicing sites. A pair of primers was designed in the identified flanking regions of the MAT1-1-1 gene (Table 3) using Primer3 and was used to amplify the alpha box domain of the MAT1-1 ORF and MAT1-1-1 genes in putative MAT1-1 isolates.

Statistical and data analyses. Measures of genetic diversity. Clone-corrected data sets were used in analyses when specified and clone correction of populations was performed in poppr using the function clonecorrect. Nei's (1978) measure of allelic diversity, allelic richness, and number of private alleles were estimated in GenAlEx. The number of MLGs, Nei's unbiased gene diversity (Nei 1978), Simpson's complement index $(1-\lambda$, a measure of genotypic diversity), evenness $\left(\mathrm{E}_{5}\right)$, and clonal fraction $(1-[\mathrm{MLG} / \mathrm{N}])$ were estimated in poppr. Significant differences in genotypic diversities for pairwise comparisons of populations was tested in GenoDive version 2.0 (Meirmans and Van Tienderen 2004) using 999 bootstrap replications.

Measures of population structure and differentiation. Analysis of molecular variance (AMOVA) was performed in GenAlEx to determine the genetic structure among $P$. betae populations (999 permutations). The pairwise index of population differentiation $\left(\Phi_{\mathrm{PT}}\right)$ (Excoffier et al. 1992) was calculated in GenAlEx (999 randomizations). Jost's measure of population differentiation (D) (Jost 2008) was calculated in the R package mmod version 1.3.3 (Winter 2012), with $95 \%$ confidence intervals estimated after 1,000 bootstrap simulations. Discriminant analyses of principal components (DAPC) (Jombart et al. 2010) was performed in adegenet. A dendrogram based on the unweighted paired group method with arithmetic mean (UPGMA) was developed based on Nei's distance (Nei 1972) in poppr.

To test for the underlying population structure without prior assignment criteria of the populations, the non-clone-corrected and clone-corrected data sets were used in three analyses. First, DAPC (Jombart et al. 2010) was performed in adegenet. Second, a UPGMA dendrogram was constructed in poppr by grouping individual isolates based on Bruvo's distance (Bruvo et al. 2004). Third, a model based Bayesian clustering method was implemented in STRUCTURE version 2.3.4 (Pritchard et al. 2000). The number of clusters $(K)$ was chosen by calculating $\Delta K$ (Evanno et al. 2005) in STRUCTURE HARVESTER version 0.6.94 (Earl and vonHoldt 2012). A graphical output was generated in CLUMPAK version 1.1 (Kopelman et al. 2015).

Tests of linkage equilibrium and recombination. The standardized index of association $\left(\bar{r}_{\mathrm{d}}\right.$ ) (Agapow and Burt 2001) was estimated after 1,000 permutations in the package poppr to investigate the null hypothesis of random mating. Rejecting this null hypothesis provides evidence for linkage disequilibrium, defined as statistical associations among different loci, which may be associated with asexual reproduction (Agapow and Burt 2001). To investigate the presence of recombination, the proportion of compatible pairs of loci ( $\mathrm{PrCP})$ (Estabrook and Landrum 1975) was calculated in Multilocus 1.3b (Agapow and Burt 2001) with 999 randomizations. Two loci are considered compatible $(\mathrm{PrCP}=1)$ if they arise from the same phylogenetic position in the absence of homoplasy (parallels, reversals, or convergences) or recombination. Under the assumption that parallels, reversals, or convergences are rare, incompatibility $(\mathrm{PrCP}<1)$ provides evidence of potential exchange of genetic material between genomes and can indicate recombination (Milgroom 2015). The hypothesis of random mating was rejected if less incompatible loci were observed than expected in a randomized population $(P<0.05)$ (Agapow and Burt 2001).

Population screening with mating type markers. Isolates of the five $P$. betae populations were assessed using primers PbMAT1-F3 and PbMAT1-R3 (MAT1-1 ORF) and PbMAT2-F and PbMAT2-R (MAT1-2 ORF) in a multiplex PCR assay. Reactions were each conducted in a total volume of $25 \mu \mathrm{l}$ and contained $1 \times$ Standard PCR buffer, $1.5 \mathrm{mM}$ of $\mathrm{MgCl}_{2}, 0.1 \mathrm{mM}$ of dNTPs, $0.1 \mu \mathrm{M}$ of each primer, $0.8 \mathrm{U}$ of Taq polymerase, and 8 to $10 \mathrm{ng}$ of template DNA. The PCR conditions included an initial denaturation for $5 \mathrm{~min}$ at $95^{\circ} \mathrm{C}$; followed by 35 cycles of denaturation at $95^{\circ} \mathrm{C}$ for $30 \mathrm{~s}$, annealing at $55^{\circ} \mathrm{C}$ for $30 \mathrm{~s}$, and extension at $68^{\circ} \mathrm{C}$ for $30 \mathrm{~s}$; and completed with a final extension at $68^{\circ} \mathrm{C}$ for $5 \mathrm{~min}$. Products from $10 \%$ of the PCR assays for the MAT1-1 and MAT1-2 ORFs were randomly selected from the five populations for sequencing at the Biotechnology Resource Center (Institute of Biotechnology, Cornell University) using an Automated 3730xl DNA Analyzer to ensure they contained the target sequence. PCR products were assessed using gel electrophoresis on a $1 \%(\mathrm{w} / \mathrm{v})$ agarose gel in Tris-acetate-EDTA amended with $0.001 \%(\mathrm{v} / \mathrm{v})$ GelRed. Product size was determined against a 100-bp DNA Ladder. A $\chi^{2}$ goodness-of-fit test (Mangiafico 2015) was performed in the $\mathrm{R}$ package stats version 3.6.0 (R Core Team 2017) for each population to test whether mating type ratios differed significantly from the $1: 1$ ratio expected in a randomly mating population.

\section{Results}

Microsatellite marker development and genotyping. Fragment analysis identified 10 markers to be reproducible (error rate $=0$ ) with only one peak per isolate. The sequences of these loci verified that they contained the target repeat motif (GenBank accessions MH823546 to MH823585; Table 2). The markers were polymorphic across all 198 isolates, with an allelic range of 4 to 33 and an average of 11.7 alleles per locus (Table 2). Nei's unbiased gene diversity ranged from 0.42 (PbSSR52) to 0.92 (PbSSR0). The genotype accumulation curve showed these markers to adequately describe the genetic variability of $P$. betae (Supplementary Fig. S1). Regenotyping $15 \%$ of the $P$. betae isolates revealed no genotyping errors with any of the primer pairs.

Mating type gene discovery and amplification. Using primers PbMAT-F2 and PbMAT-R3 to amplify the MAT1 locus in two MAT1-2 isolates and two putative MAT1-1 isolates, both MAT1-2 isolates $(\mathrm{Pb} 1$ and $\mathrm{Pb} 2)$ produced a $\mathrm{PCR}$ product of $3,714 \mathrm{bp}$, and the putative MAT1-1 isolates amplified 3,809-bp (Phb51) and 3,823-bp (CBS 109410) PCR products, respectively (Genbank accessions MH823586, MH823587, MH823588, and MH823589). For both MAT1-1 and MAT1-2, FGENESH+ predicted one protein and two exon sites. A 50-bp intron was identified in the MAT1-1 ORF (data not shown).

Genetic diversity of $\boldsymbol{P}$. betae populations. High genotypic diversity and moderate allelic diversity were quantified in all five $P$. betae populations (Table 4). Simpson's complement index $(1-\lambda$, a measure of genotypic diversity) ranged from 0.857 (NY1) to 0.924 (WA1). No significant $(P>0.08)$ difference was found in genotypic diversity by pairwise comparisons of populations. Nei's unbiased gene diversity ranged from 0.582 (NY1) to 0.653 (WA1). Across 175 isolates, 64 unique MLGs were found, along with a $63 \%$ clonal fraction. WA1 had the smallest clonal fraction (0.429) and the greatest number of unique alleles per locus, with 13 private alleles (alleles not shared with isolates in other populations). NY1 had the largest clonal fraction (0.686). Seventy isolates had recurrent MLGs. MLG.50 was shared the most frequently and was present in 22 
isolates in the Washington populations (Supplementary Fig. S2). In each population, all loci were polymorphic.

Genetic differentiation of $\boldsymbol{P}$. betae populations. The majority of genetic diversity detected was among individual isolates within populations. AMOVA of the non-clone-corrected data set found $87 \%$ of the genetic diversity attributed to variation among isolates within populations and $13 \%$ among the five populations $\left(\Phi_{\mathrm{PT}}=0.127\right.$; $P=0.001)$. After clone correction, $96 \%$ of the observed genetic diversity was partitioned among isolates within populations and $4 \%$ among the populations $\left(\Phi_{\mathrm{PT}}=0.038 ; P=0.004\right)$.

Two pairwise indices of differentiation detected low but significant levels of genetic differentiation between populations in the non-clone-corrected and clone-corrected data sets. In the nonclone-corrected data set, $\Phi_{\mathrm{PT}}$ values were low, ranging from 0.045 to 0.174 , with the largest differentiation detected between the WA1 and NY1 populations $(0.174 ; P=0.001)$ and the smallest differentiation between the NY1 and NY2 populations $(0.045 ; P=0.009)$. After clone correction, the WA1 and NY2 populations showed small, although significant, genetic differentiation $(0.099 ; P=0.001)$, but the differentiation between the NY1 and NY2 populations and the WA2 and WA3 populations was not significant $(P>0.05)$ (Table 5). Jost's D values corroborated these trends. In the nonclone-corrected data set, Jost's D values ranged from 0.091 to 0.356 , with the largest differentiation again detected between the WA1 and NY1 populations $(0.356 ; 95 \%$ confidence interval $=$ 0.285 to 0.426 ) and the smallest differentiation again detected between the NY1 and NY2 populations $(0.091 ; 95 \%$ confidence interval $=0.040$ to 0.141$)$. After clone correction, Jost's $D$ values decreased between all populations and trends persisted (Table 5).

Population structure of $\boldsymbol{P}$. betae populations. In the non-clonecorrected and clone-corrected data sets, UPGMA dendrograms based on Nei's genetic distance identified two major clusters of $P$. betae populations distinguished by state (Fig. 1). DAPC using predefined populations also demonstrated that individuals in each population mostly clustered together by state (Fig. 2). The first principal component of DAPC (horizontal axis) revealed that the WA1 population was genetically more similar to WA2 and WA3 than the New York populations, whereas the second principal component (vertical axis) separated the WA1 population from WA2 and WA3, suggesting population structure within Washington (Fig. 2).

In the clone-corrected data set, population structure analysis with no a priori population assignment using DAPC analysis detected three distinct clusters, which contained 17, 41, and 17 individuals (Fig. 3). Cluster membership did not necessarily correlate to population assignment (Supplementary Table S2). DAPC clusters 2 through 5 are also shown (Supplementary Fig. S3). The UPGMA dendrogram based on Bruvo's distance grouped the $P$. betae isolates into two main clades that were not necessarily differentiated by state (Fig. 4). Bayesian clustering analysis in STRUCTURE also resulted in the detection of three distinct clusters (Supplementary Fig. S4), consisting of 38, 19, and 18 individuals (Supplementary Fig. S5). Incongruence among DAPC, the UPGMA dendrogram, and STRUCTURE clusters was observed (Fig. 4). For the non-clone-corrected data set, DAPC analysis was inconclusive as the Bayesian information criterion values consistently decreased with the number of clusters until
$K$ reached the total number of MLGs, the UPGMA dendrogram based on Bruvo's distance grouped the $P$. betae isolates into two main clades, and STRUCTURE detected two distinct clusters (data not shown).

Linkage disequilibrium of $\boldsymbol{P}$. betae populations. For the nonclone-corrected data set, the calculated standardized index of association $\left(\bar{r}_{\mathrm{d}}\right)$ resulted in rejection of the null hypothesis of random mating for all five populations $(P<0.001)$. In the clone-corrected data set, the calculated $\bar{r}_{\mathrm{d}}$ also resulted in rejection of the null hypothesis of random mating for all populations $(P<0.001)$ except WA1 $(P=$ $0.064)$ (Table 6). PrCP values were significant $(P<0.045)$ for all populations except WA1 $(P=0.06)$, providing further evidence to reject the null hypothesis of random mating among isolates in all but the WA1 population. PrCP ranged from 0.089 (WA1) to 0.733 (NY2). In WA1, 91\% pairs of loci were incompatible (Table 6). The three clusters detected by STRUCTURE rejected the null hypothesis of random mating in linkage disequilibrium analyses. The calculated $\bar{r}_{\mathrm{d}}$ for the three clusters ranged from 0.016 (cluster 1 ) to 0.215 (cluster 2$)(P<0.04)$. PrCP values were significant $(P<$ $0.001)$ for all clusters except cluster $1(P=1)$, providing further evidence to reject the null hypothesis of random mating among isolates in the genetically distinct clusters.

Mating type ratios. Primers designed to amplify the alpha box region of MAT1-1-1 in P. betae isolates produced a product of $162 \mathrm{bp}$ (GenBank accessions MH823590 to MH823599). Primers designed to amplify the HMG DNA-binding domain of MAT1-2-1 in P. betae isolates produced a product of $277 \mathrm{bp}$ (GenBank accessions MH823600 to MH823606). In three of the five populations (WA2, NY1, and NY2), ratios of MAT1-1 and MAT1-2 isolates did not differ significantly from $1: 1(P>0.05)$ (Table 6$)$, suggesting panmixis for these populations. In populations WA1 and WA3, the ratio of

Table 5. Pairwise indices of differentiation ( $\Phi_{\mathrm{PT}}$ and Jost's D values) for clone-corrected data of five Phoma betae populations from Washington and New York states

\begin{tabular}{|c|c|c|}
\hline \multirow[b]{2}{*}{ Population pair ${ }^{\mathbf{a}}$} & \multicolumn{2}{|c|}{ Index of differentiation } \\
\hline & $\overline{\Phi_{\mathrm{PT}}(P \text { value })^{\mathbf{b}}}$ & Jost's D $(95 \%$ CI) \\
\hline WA1-WA2 & $0.005(0.360)$ & 0.093 (0.006 to 0.180$)$ \\
\hline WA1-WA3 & $0.026(0.063)$ & 0.129 (0.036 to 0.222$)$ \\
\hline WA1-NY1 & $0.062(0.004)^{\mathrm{d}}$ & $0.240(0.138$ to 0.341$)$ \\
\hline WA1-NY2 & $0.099(0.001)^{\mathrm{d}}$ & 0.324 (0.209 to 0.438$)$ \\
\hline WA2-WA3 & $0(0.431)$ & $0.067(-0.025$ to 0.160$)$ \\
\hline WA2-NY1 & $0.02(0.186)$ & 0.145 (0.032 to 0.257$)$ \\
\hline WA2-NY2 & $0.033(0.102)$ & 0.160 (0.052 to 0.268$)$ \\
\hline WA3-NY1 & $0.052(0.018)^{\mathrm{d}}$ & 0.196 (0.091 to 0.301$)$ \\
\hline WA3-NY2 & $0.073(0.006)^{\mathrm{d}}$ & $0.230(0.124$ to 0.336$)$ \\
\hline NY1-NY2 & $0(0.433)$ & $0.066(-0.038$ to 0.169$)$ \\
\hline
\end{tabular}

a WA1, WA2, and WA3 represent three populations of $P$. betae isolates from Washington. NY1 and NY2 = two populations of $P$. betae isolates from New York.

${ }^{\mathrm{b}} \Phi_{\mathrm{PT}}=$ pairwise index of population differentiation.

${ }^{\mathrm{c}} \mathrm{D}$ = Jost's measure of population differentiation (Winter 2012), and CI = confidence interval.

${ }^{\mathrm{d}}$ These $\Phi_{\mathrm{PT}}$ values (Excoffier et al. 1992) had $P$ values $<0.05$.

Table 4. Indices of genetic diversity for non-clone-corrected data of five Phoma betae populations from Washington and New York states ${ }^{\mathrm{a}}$

\begin{tabular}{lcccccccc}
\hline Population & $\mathbf{N}$ & MLG & $\mathbf{1}-\boldsymbol{\lambda}^{\mathbf{b}}$ & $\mathbf{E . 5}$ & $\mathbf{H}$ & $\mathbf{C F}_{\mathbf{a}}$ & $\mathbf{P}_{\mathbf{a}}$ \\
\hline WA1 & 35 & 20 & 0.924 & 0.646 & 0.653 & 0.429 & 13 & 6 \\
WA2 & 35 & 14 & 0.871 & 0.652 & 0.628 & 0.6 & 5.7 \\
WA3 & 35 & 17 & 0.897 & 0.656 & 0.605 & 0.514 & 8 \\
NY1 & 35 & 11 & 0.857 & 0.735 & 0.582 & 0.686 & 8 \\
NY2 & 35 & 13 & 0.913 & 0.820 & 0.622 & 0.629 & 8.3 \\
Total & 175 & 64 & 0.963 & 0.601 & 0.69 & 0.634 & - \\
\hline
\end{tabular}

${ }^{\mathrm{a}} \mathrm{N}=$ Number of isolates, MLG = multilocus genotypes detected from alleles at 10 microsatellite loci, E.5 = evenness (a measure of the uniformity of the distribution of MLGs in a population; Ludwig and Reynolds 1988), $\mathrm{H}=$ Nei's unbiased gene diversity (Nei 1978), CF = clonal fraction, $\mathrm{P}_{\mathrm{a}}=$ private allele $(\mathrm{Peakall}$ and Smouse 2006), and $\mathrm{N}_{\mathrm{a}}=$ mean number of alleles per locus. Dashes indicate that statistic is not listed for the total population.

b $1-\lambda=$ Simpson's complement index. $\lambda=\sum p_{i}^{2}$, where $p$ is the frequency of the $i$ th genotype in a population (Simpson 1949). Values range from 0 (no genotypes are different) to 1 (all genotypes are different) and is corrected for sample size by multiplying by $\mathrm{N} /(\mathrm{N}-1)$. 
MAT1-1 and MAT1-2 isolates did deviate significantly from 1:1 $(P<0.004)$.

\section{Discussion}

To our knowledge, this is the first study to investigate the population biology of $P$. betae from table beet root and seed fields in the United States. Robust microsatellite and mating type markers were developed as a tool to genotype $P$. betae populations. Microsatellite markers were validated on 175 isolates and demonstrated the ability to sufficiently capture the genetic diversity exhibited by $P$. betae populations from two states, New York and Washington. High genotypic diversity and moderate allelic diversity were detected in $P$. betae populations from New York and Washington. The relationships

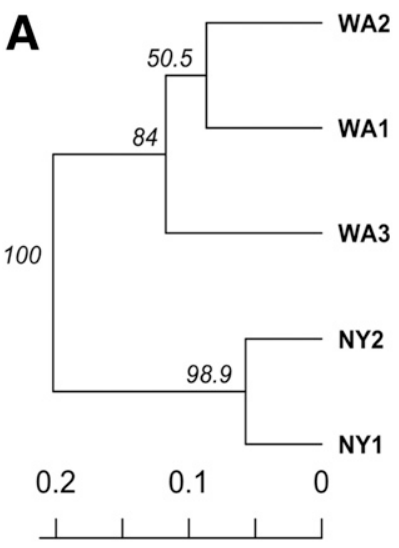

Nei's Genetic Distance

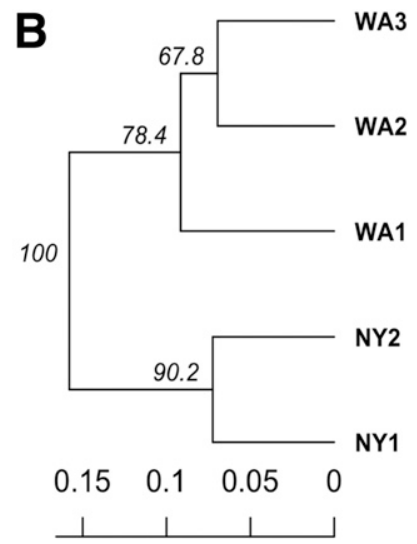

Nei's Genetic Distance
Fig. 1. Dendrogram of the relationships among $\mathbf{A}$, non-clone-corrected and $\mathbf{B}$, clonecorrected Phoma betae populations from New York (NY1 and NY2) and Washington (WA1 to WA3) states. The dendrogram was constructed using the unweighted pair group method with arithmetic mean based on Nei's (1972) genetic distance. Numbers at branch points indicate the percent occurrence of the cluster to the right of the branch in 1,000 bootstrapped dendrograms. between these populations offer insights into the spread and biology of $P$. betae across the United States.

$P$. betae populations had significant but low genetic differentiation among the five locations sampled (three in Washington and two in New York). Despite the overall limited differentiation among the five populations, the two $P$. betae populations from New York were differentiated from the three Washington populations. Based on DAPC analysis using predefined populations, those within each state clustered closer together than those between states. Six of eight shared MLGs were only shared among populations in the same state. The remaining two shared MLGs (MLG.27 and MLG.33) were among the WA2, NY1, and NY2 populations. The UPGMA dendrogram based on Nei's (1972) distance also divided the populations into two main groups based on states. After clone correction, genetic differentiation decreased although general genetic differentiation trends persisted and differentiation between the New York populations was no longer significant. Taken together, these results suggested the presence of two populations of $P$. betae, one in Washington and one in New York, and the dominant role of an external source of inoculum, such as windblown ascospores, contributing to homogeneity between populations within each state. Further studies designed to analyze isolation by distance of $P$. betae populations may be warranted.

Alternatively, $P$. betae has been reported multiple times to enter fields externally through infected beet seed (Edson 1915; Herr 1971; Leach and MacDonald 1976; Mangan 1971). Infected plants that do not succumb to damping-off from seedborne $P$. betae can persist and be a source of inoculum for the development of Phoma leaf spot and/or root rot and decay in storage (Bugbee and Soine 1974; Edson 1915). Edson (1915) estimated that up to $75 \%$ of seedlings infected with $P$. betae can survive under favorable environmental conditions. Moreover, Bugbee (1982) estimated that $P$. betae can remain latent for up to 100 days in storage before causing root rot. Despite the fact that much of the seed planted in New York originates from the maritime Pacific Northwest United States (western Washington and Oregon), and distinct differentiation was observed between $P$. betae populations from New York and Washington, greater understanding of the mycoflora of table beet seed planted in New York would be valuable.

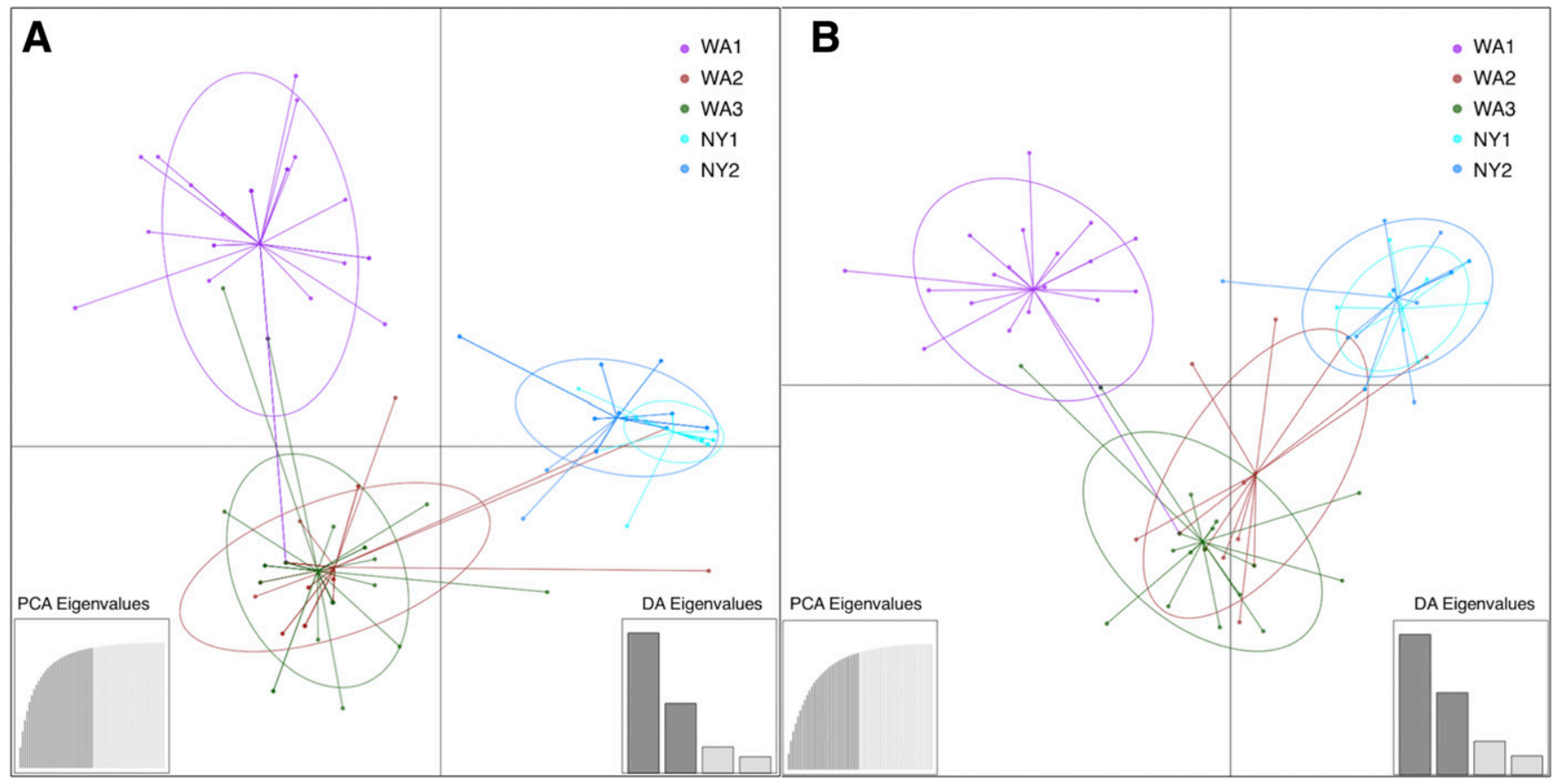

Fig. 2. Discriminant analysis of principal components (DAPC) for the A, non-clone-corrected and B, clone-corrected Phoma betae populations from New York (NY1 and NY2) and Washington (WA1 to WA3) states. The scatterplots show the first two principal components of the DAPC, and $P$. betae populations are used as prior clusters. Eigenvalues signifying the variance explained by principal component analysis (PCA) and discriminant analysis (DA) indicated that the first two principal components adequately explain the genetic structure of the populations. Points represent individual isolates and ellipses represent individual populations. 
Furthermore, although this study of $P$. betae in New York and Washington did not directly assess the impact of seedborne inoculum of $P$. betae in disease outbreaks, population biology studies investigating the contribution of isolates from infected seed to field outbreaks would be useful. For example, the mark-release-recapture strategy has been used to investigate the importance of various inoculum sources contributing to different diseases (Bennett et al. 2007; Muzhinji et al. 2018; Zhan and McDonald 2013). Bennett et al. (2007) marked winter wheat seed by infecting it with two groups of genetically distinct isolates of Phaeosphaeria nodorum, released the isolates by planting infected seed in the field, and recaptured them by sampling throughout the growing seasons in Georgia and New York. In that study, seed-transmitted genotypes accounted for over half of all recovered isolates; however, the high frequency of novel genotypes suggested that other inoculum sources may also be important in initiating disease outbreaks (Bennett et al. 2007).

Results of this study indicated that inoculum originating from outside table beet fields may be important; however, within-field sources of inoculum cannot be disregarded, as $P$. betae has alternative hosts beyond subspecies of $B$. vulgaris. In addition to sugar beet, table beet, and Swiss chard, P. betae has been reported to infect Aloe vera, Spinacia oleracea (spinach), C. album, and Avena sativa (oat) (Avasthi et al. 2013; Bassimba et al. 2014; Bugbee and Soine 1974). P. betae has also been reported as an endophyte on Anisomeles malabarica and Ginkgo biloba (maiden hair tree) (Jayanthi et al. 2014; Kumaran et al. 2012). Further studies evaluating local weeds and crops found in typical New York and Washington rotations are hence warranted.

The limited but significant genetic differentiation observed across populations of $P$. betae in New York and Washington in this study corroborates the finding of the greatest genetic diversity occurring within populations rather than among populations. Structuring of the $P$. betae populations among each field suggests that local inoculum source(s) may also play a role within each field surveyed. Studies of $P$. betae populations in a field over time may be useful to investigate hypotheses concerning sources of inoculum for initiating disease outbreaks (Grünwald et al. 2017; Milgroom 2015). For example, Knight et al. (2018) sampled $C$. beticola populations in three table beet fields over a 2 -year period in New York and found populations to be genetically distinct each year, suggesting that the primary inoculum was originating from external sources in some instances.

Microsatellite markers and mating type markers were used to explore the reproductive strategy of $P$. betae populations in this study. All populations appeared to experience a mixed reproductive mode of sexual and asexual reproduction, showing evidence of both random mating and clonality. Signs of random mating consisted of evidence for recombination, including high genotypic diversity and incongruence among the STRUCTURE, DAPC, and UPGMA dendrogram clusters. Similar findings have been described for C. beticola populations on table beet (Vaghefi et al. 2017b). Recombination may have a direct role in generating genotypic diversity (Diao et al. 2015; Liang et al. 2009; Vaghefi et al. 2017b). The mating type ratios in three of the five $P$. betae populations examined in this study were not significantly different from a 1:1 ratio, providing additional support for random mating.

Evidence for clonality in the five populations of $P$. betae sampled from New York and Washington included moderate clonal fractions ( 0.429 to 0.686$)$ and linkage disequilibrium. Besides a lack of recombination, linkage disequilibrium may result from selection, linkage, population admixture, and random genetic drift (Milgroom 2015). After clone correction, the standardized index of association values did not differ significantly from zero in the WA1 population, resulting in failure to reject the null hypothesis of random mating. For the remaining four populations, the null hypothesis of random mating was rejected. PrCP values also rejected the null hypothesis of random mating in all populations except for WA1. Tests of random mating conducted on the three major clusters detected by STRUCTURE analysis also were found to reject the null hypothesis of random mating, confirming that the detected linkage disequilibrium was not a function of population structure. This provides evidence for mixed modes of reproduction in $P$. betae populations. To explain genetic diversity observed in populations, other population biology studies on fungal pathogens have postulated that fungi predominantly undergo

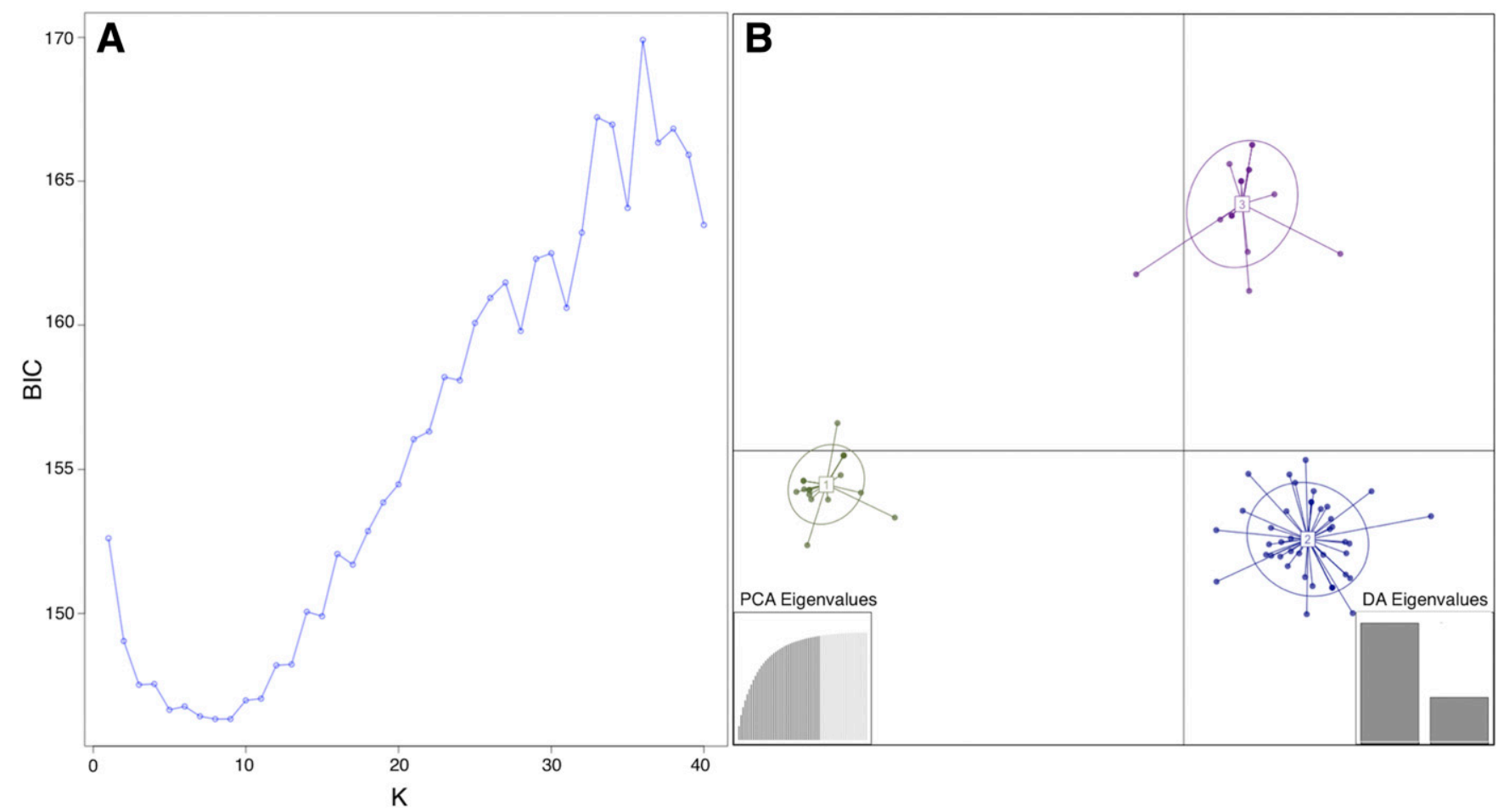

Fig. 3. Discriminant analysis of principal components (DAPC) for the clone-corrected data set of Phoma betae populations from New York and Washington. A, Graph of Bayesian information criterion (BIC) values for different numbers of clusters (K). B, Scatterplot representing the three genetically distinct clusters of $P$. betae isolates as determined by DAPC analysis. $\mathrm{PCA}=$ principal component analysis, $\mathrm{DA}=$ discriminant analysis. 


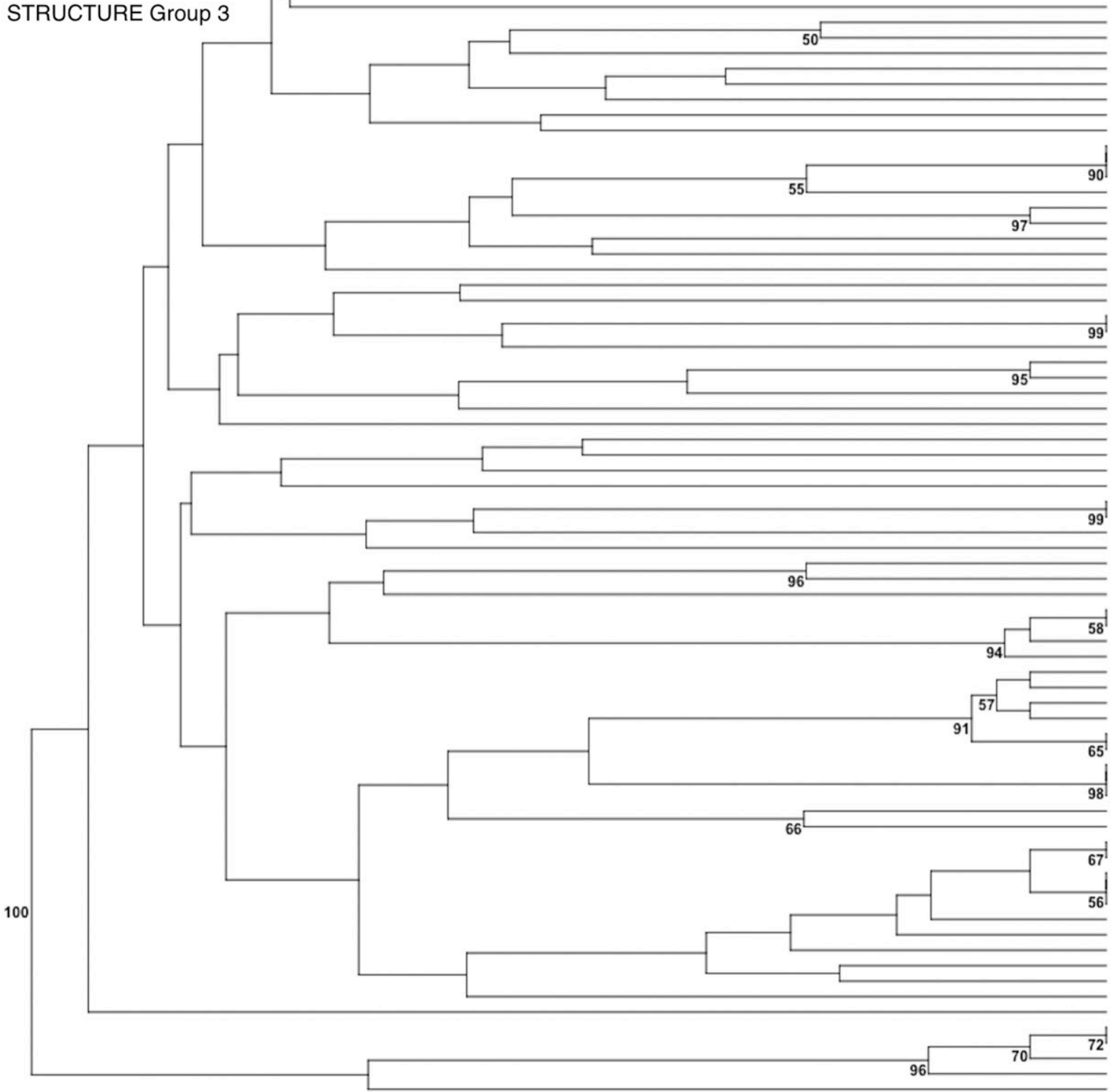

0

\begin{tabular}{cccc}
0.3 & 0.2 & 0.1 & 0 \\
1 & 1 & 1 & \multicolumn{1}{c}{ Bruvo's Genetic Distance }
\end{tabular}

Fig. 4. A dendrogram based on the unweighted pair group method with arithmetic mean for the clone-corrected data of Phoma betae isolates from New York (TR and RN) and Washington (Phb) states based on Bruvo's distance (Bruvo et al. 2004). Bootstrap support $>50$ is shown. Isolate color corresponds to discriminant analysis of principal components grouping color (green = cluster 1, blue = cluster 2, and purple = cluster 3) (Jombart et al. 2010). The color of the bar next to each isolate indicates the STRUCTURE grouping (Pritchard et al. 2000)

Table 6. Standardized index of association, proportion of compatible pairs of loci, and mating type frequencies (MAT1-1 and MAT1-2) in the clone-corrected populations of Phoma betae from table beet root crops in New York (NY1 and NY2) and table beet seed crops in Washington (WA1 to WA3) states

\begin{tabular}{llcrr}
\hline Population & $\overline{\boldsymbol{r}}_{\mathbf{d}}(\boldsymbol{P} \text { value })^{\mathbf{a}}$ & ${\text { PrCP observed }(\boldsymbol{P} \text { value })^{\mathbf{b}}}$ & MAT1-1 & $\boldsymbol{M}^{\mathbf{2 c}}$ \\
\hline WA1 & $0.0209(0.064)$ & $0.089(0.060)$ & 26 & 9 \\
WA2 & $0.1012(<0.001)$ & $0.578(0.001)$ & 21 & $3.26^{\mathrm{d}}$ \\
WA3 & $0.0654(0.002)$ & $0.378(0.002)$ & 13 & 1.40 \\
NY1 & $0.1638(<0.001)$ & $0.667(0.045)$ & 15 & 5 \\
NY2 & $0.1997(<0.001)$ & $0.733(<0.001)$ & 22 & $2.86^{\mathrm{d}}$ \\
\hline
\end{tabular}

$\mathrm{a} \bar{r}_{\mathrm{d}}=$ standardized index of association (Agapow and Burt 2001).

${ }^{\mathrm{b}} \mathrm{PrCP}=$ proportion of phylogenetically comparable pairs of loci. "Observed" indicates the observed value. $P$ values $<0.05$ were considered significant $($ Agapow and Burt 2001).

${ }^{c} \chi^{2}$ value based on a 1:1 ratio and one degree of freedom.

${ }^{\mathrm{d}}$ These mating-type frequencies had a significant deviation from the 1:1 ratio $(P<0.05)$. 
asexual reproduction with occasional recombination (Burt et al. 1996; Romero Luna et al. 2017; Taylor et al. 1999; Vaghefi et al. 2017b).

Maintaining both sexual and asexual reproduction may enable $P$. betae to adapt readily to different hosts and environments (Calo et al. 2013). When interpreting the results of this study, it is important to emphasize that population genetic analyses can only provide indirect evidence for sexual reproduction and recombination. Recombination may allow organisms to adapt to new environments and purge deleterious mutations (Zeyl and Bell 1997). This study found high genotypic diversity among five populations of $P$. betae from two states, indicating the potential for the fungus to adapt to selection pressures such as predominant use of fungicides with single-site modes of action (Milgroom 1996). Recombination, random mating tests, and molecular-based evidence of sex (presence of both mating types) also suggest the occurrence of a sexual cycle (Milgroom 2015). Evidence of sexual reproduction within populations of $P$. betae (i.e., the presence of pseudothecia) has been observed in the United Kingdom and midwestern United States (Bugbee 1979; Cornford 1958), but not in New York. The production of pseudothecia can have a significant impact on survival and dispersal of the fungus and has previously been observed in sugar beet infested debris (Duffus and Ruppel 1995). Bugbee (1979) also observed pseudothecia on inoculated sugar beet stem pieces in North Dakota and plant debris following harvest of sugar beet seed crops in Oregon. Pathogenicity testing with sugar beet revealed infections arising from $P$. betae ascospores to result in more severe root rot than those initiated from conidia (Bugbee 1979). Observation and depiction of temporal dynamics of pseudothecia production in infested plant material in fields will enhance understanding of the biology of this pathosystem under local conditions.

This study developed microsatellite and mating type markers for $P$. betae that can be used to characterize populations of $P$. betae in future studies. The high genotypic diversity observed in all populations suggested that a larger population sample size may be useful in future assessments. Evidence for the presence of two populations distinguished by state of origin, New York and Washington, suggested that inoculum of $P$. betae disease outbreaks in these regions may originate predominantly from an external source, such as ascospores or seeds, and that dispersal of inoculum between states is not frequent. Despite evidence for external inoculum sources, the structure observed in individual populations provided evidence that local inoculum sources such as infected alternative hosts or soilborne inoculum associated with infested crop debris cannot be discounted. Further assessment of inoculum sources of $P$. betae causing disease outbreaks is warranted. Investigation of $P$. betae reproductive strategies in this study provided evidence for a mixed reproductive mode occurring in all five populations. Direct observation of pseudothecia, as an indication of sexual reproduction in the field, would also be instrumental to a comprehensive understanding of the role of overwintering inoculum and dispersal of $P$. betae in outbreaks.

\section{Acknowledgments}

This study formed a portion of research submitted in partial fulfillment of the requirements for a Master of Science degree for L. B. Koenick. We thank Carol Bowden, Sean Murphy, Matt Schwarzkopf, and David Strickland at Cornell University and Mike Derie and Barbara Holmes at Washington State University for excellent technical support. We are also grateful to the table beet growers in New York and table beet seed growers and seed companies in Washington who allowed access to fields for collection of diseased plant material. Author contributions (listed alphabetically within each section): du Toit and Pethybridge obtained funding; du Toit collected isolates in WA; Koenick, Pethybridge, and Vaghefi collected isolates in NY; du Toit, Koenick, Pethybridge, and Vaghefi conceived and designed the experiments; Koenick performed the experiments; Koenick, Knight, and Pethybridge analyzed the data; du Toit and Pethybridge contributed reagents/ materials and analysis tools; du Toit, Koenick, Knight, Pethybridge, and Vaghefi wrote the paper.

\section{Literature Cited}

Abawi, G. S., Crossier, D. C., Cobb, A. C., and Becker, R. F. 1986. Root rot of table beets in New York State. N. Y. Food Life Sci. Bull. 115:1-8.
Agapow, P.-M., and Burt, A. 2001. Indices of multilocus linkage disequilibrium. Mol. Ecol. Notes 1:101-102.

Ariyawansa, H. A., Thambugala, K. M., Manamgoda, D. S., Jayawardena, R., Camporesi, E., Boonmee, S., Wanasinghe, D. N., Phookamsak, R., Hongsanan, S., Singtripop, C., Chukeatirote, E., Kang, J.-C., Jones, E. B. G., and Hyde, K. D. 2015. Towards a natural classification and backbone tree for Pleosporaceae. Fung. Div. 71:85-139.

Avasthi, S., Gautam, A. K., and Bhadauria, R. 2013. First report of Phoma betae on Aloe vera in India. Arch. Phytopathol. Plant Prot. 46:1508-1511.

Aveskamp, M. M., de Gruyter, J., Woudenberg, J. H. C., Verkley, G. J. M., and Crous, P. W. 2010. Highlights of the Didymellaceae: A polyphasic approach to characterize Phoma and related Pleosporalean genera. Stud. Mycol. 65:1-60.

Aveskamp, M. M., Verkley, G. J. M., de Gruyter, J., Murace, M. A., Perelló, A., and Woudenberg, J. H. C. 2009. DNA phylogeny reveals polyphyly of Phoma section Peyronellaea and multiple taxonomic novelties. Mycologia 101: 363-382.

Banke, S., and McDonald, B. A. 2005. Migration patterns among global populations of the pathogenic fungus Mycosphaerella graminicola. Mol. Ecol. 14:1881-1896.

Bassimba, D. D. M., Mira, J. L., and Vicent, A. 2014. First report of leaf spot of spinach caused by Pleospora betae in Spain. Plant Dis. 98:1583.

Bennett, R. S., Milgroom, M. G., Sainudiin, R., Cunfer, B. M., and Bergstrom, B. C. 2007. Relative contribution of seed-transmitted inoculum to foliar populations of Phaeosphaeria nodorum. Phytopathology 97:584-591.

Benson, G. 1999. Tandem repeats finder: A program to analyze DNA sequences. Nucleic Acids Res. 27:573-580.

Bruford, M. W., and Wayne, R. K. 1993. Microsatellites and their application to population genetic studies. Curr. Opin. Genet. Dev. 3:939-943.

Bruvo, R., Michiels, N. K., D’Souza, T. G., and Schulenburg, H. 2004. A simple method for the calculation of microsatellite genotype distances irrespective of ploidy level. Mol. Ecol. 13:2101-2106.

Bugbee, W. M. 1979. Pleospora bjoerlingii in the USA. Phytopathology 69: 277-278.

Bugbee, W. M. 1982. Storage rot of sugar beet. Plant Dis. 66:871-873

Bugbee, W. M., and Cole, D. F. 1981. The effect of seed infected with Phoma betae and sucrose yield of stored sugar beet. Phytopathology 71:357-359.

Bugbee, W. M., and Soine, O. C. 1974. Survival of Phoma betae in soil. Phytopathology 64:1258-1260.

Burt, A., Carter, D. A., Koenig, G. L., White, T. J., and Taylor, J. W. 1996 Molecular markers reveal cryptic sex in the human pathogen Coccidioides immitis. Proc. Natl. Acad. Sci. USA 93:770-773.

Calo, S., Billmyre, R. B., and Heitman, J. 2013. Generators of phenotypic diversity in the evolution of pathogenic microorganisms. PLoS Pathog 9:e1003181.

Carbone, I., and Kohn, L. M. 2004. Inferring process from pattern in fungal population genetics. Pages 29-58 in: Fungal Genomics, Applied Mycology and Biotechnology. D. K. Arora and G. G. Khachatourians, eds. Elsevier Science, Amsterdam.

Clark, K., Karsch-Mizrachi, I., Lipman, D. J., Ostell, J., and Sayers, E. W. 2016 GenBank. Nucleic Acids Res. 44:D67-D72.

Coppin, E., Debuchy, R., Arnaise, S., and Picard, M. 1997. Mating types and sexual development in filamentous ascomycetes. Microbiol. Mol. Biol. Rev. 61:411-428.

Cornford, C. E. 1958. Perfect state of Phoma betae found in England. Plant Pathol 7:113-114.

de Gruyter, J., Woudenberg, J. H. C., Aveskamp, M. M., Verkley, G. J. M., Groenewald, J. Z., and Crous, P. W. 2013. Redisposition of Phoma-like anamorphs in Pleosporales. Stud. Mycol. 75:1-36.

Debuchy, R., and Turgeon, B. G. 2006. Mating-type structure, evolution, and function in Euascomycetes. Pages 293-323 in: The Mycota. U. Kues and R. Fischer, eds. Vol. I. Springer-Verlag, Berlin.

Diao, Y., Zhang, C., Xu, J., Lin, D., Lui, L., Mtung'e, O. G., and Lui, X. 2015. Genetic differentiation and recombination among geographic populations of the fungal pathogen Colletotrichum truncatum from chili peppers in China. Evol. Appl. 8:108-118.

du Toit, L. J. 2007. Crop profile for table beet seed in Washington. U.S Department of Agriculture Pest Management Centers. https://ipmdata. ipmcenters.org/documents/cropprofiles/WAbeetseed2007.pdf

du Toit, L. J. 2017. Phoma betae in table beet and Swiss chard seed crops in Washington. Pages 27-31 in: Northwest Agricultural Research Foundation and Affiliated Organizations: 2017 Research Proposals and 2016 Research Reports. Washington State University Mount Vernon Northwestern Washington Research and Extension Center, Mount Vernon, WA.

Duffus, J. E., and Ruppel, E. G. 1995. Major fungal diseases. Pages 369-393 in: The Sugar Beet Crop. D. A. Cooke and R. K. Scott, eds. Chapman \& Hall, London.

Earl, D. A., and vonHoldt, B. M. 2012. STRUCTURE HARVESTER: A website and program for visualizing STRUCTURE output and implementing the Evanno method. Conserv. Genet. Resour. 4:359-361.

Edson, H. A. 1915. Seedling diseases of sugar beets and their relation to root-rot and crown-rot. J. Agric. Res. 4:135-168.

Ellegren, H. 2004. Microsatellites: Simple sequences with complex evolution. Nat. Rev. Genet. 5:435-445.

Estabrook, G., and Landrum, L. 1975. A simple test for the possible simultaneous evolutionary divergence of two amino acid positions. Taxon 24:609-613. 
Estoup, A., and Guillemaud, T. 2010. Reconstructing the routes of invasion using genetic data: Why, how and so what? Mol. Ecol. 19:4113-4130.

Evanno, G., Regnaut, S., and Goudet, J. 2005. Detecting the number of clusters of individuals using the software structure: A simulation study. Mol. Ecol. 14: 2611-2620.

Excoffier, L., Smouse, P. E., and Quattro, J. M. 1992. Analysis of molecular variance inferred from metric distances among DNA haplotypes: Application to human mitochondrial DNA restriction data. Genetics 131:479-491.

Goss, E. M., Tabima, J. F., Cooke, D. E. L., Restrepo, S., Fry, W. E., Forbes, G. A., Fieland, V. J., Cardenas, M., and Grünwald, N. J. 2014. The Irish potato famine pathogen Phytophthora infestans originated in central Mexico rather than the Andes. Proc. Natl. Acad. Sci. USA 111:8791-8796.

Grünwald, N. J., Everhart, S. E., Knaus, B. J., and Kamvar, Z. N. 2017. Best practices for population genetic analyses. Phytopathology 107:1000-1010.

Grünwald, N. J., Garbelotto, M., Goss, E. M., Heungens, K., and Prospero, S. 2012. Emergence of the sudden oak death pathogen Phytophthora ramorum. Trends Microbiol. 20:131-138.

Grünwald, N. J., and Goss, E. M. 2011. Evolution and population genetics of exotic and re-emerging pathogens: novel tools and approaches. Annu. Rev. Phytopathol. 49:249-267.

Harveson, R. M., Hanson, L. E., and Hein, G. L. 2009. Compendium of Beet Diseases and Pests, 2nd ed. American Phytopathological Society Press, St. Paul, MN.

Herr, L. J. 1971. Hot water treatment for elimination of seed-borne Phoma betae and other microbial contaminants from sugar beet seed. J. Am. Soc. Sugar Beet Technol. 16:568-574.

Holleley, C. E., and Geerts, P. G. 2009. Multiplex Manager 1.0: A cross-platform computer program that plans and optimizes multiplex PCR. Biotechniques 46:511-517.

International Seed Testing Association. 1982. Beet damping-off, blackleg. Beta vulgaris, Phoma betae. Working Sheet No. 49. ISTA Handbook on Seed Health Testing. International Seed Testing Association, Zurich, Switzerland.

Jayanthi, G., Karthikeyan, K., and Muthumary, J. 2014. Pervasiveness of endophytic fungal diversity in Anisomeles malabarica from Aliyar, Western Ghats, South India. Mycosphere 5:830-840.

Jeffers, S. 2015. PROTOCOL 07-11.1: V8 agar (V8A) or broth. Pages 1-2 in: Laboratory Protocols for Phytophthora Species. American Phytopathological Society Press, St. Paul, MN.

Jombart, T., Devillard, S., and Balloux, F. 2010. Discriminant analysis of principal components: A new method for the analysis of genetically structured populations. BMC Genet. 11:94.

Jost, L. 2008. GST and its relatives do not measure differentiation. Mol. Ecol. 17: 4015-4026.

Kamvar, Z. N., Brooks, J. C., and Grünwald, N. J. 2015. Novel R tools for analysis of genome-wide population genetic data with emphasis on clonality. Front. Genet. 6:208.

Kamvar, Z. N., Tabima, J. F., and Grünwald, N. J. 2014. Poppr: An R package for genetic analysis of populations with clonal, partially clonal, and/or sexual reproduction. PeerJ 2:e281.

Kearse, M., Moir, R., Wilson, A., Stones-Havas, S., Cheung, M., Sturrock, S., Buxton, S., Cooper, A., Markowitz, S., Duran, C., Thierer, T., Ashton, B., Mentjies, P., and Drummond, A. 2012. Geneious Basic: An integrated and extendable desktop software platform for the organization and analysis of sequence data. Bioinformatics 28:1647-1649.

Knight, N. L., Vaghefi, V., Hansen, Z. R., Kikkert, J. R., and Pethybridge, S. J. 2018. Temporal genetic differentiation of Cercospora beticola populations in New York table beet fields. Plant Dis. 102:2074-2082.

Kopelman, N. M., Mayzel, J., Jakobsson, M., Rosenberg, N. A., and Mayrose, I. 2015. CLUMPAK: A program for identifying clustering modes and packaging population structure inferences across K. Mol. Ecol. Resour. 15:1179-1191.

Kumaran, R. S., Choi, Y. K., Lee, S., Jeon, H. J., Jung, H., and Kim, H. J. 2012. Isolation of taxol, an anticancer drug produced by the endophytic fungus, Phoma betae. Afr. J. Biotechnol. 11:950-960.

Leach, L. D., and MacDonald, L. D. 1976. Seed-borne Phoma betae as influenced by area of sugarbeet production, seed processing and fungicidal seed treatments. J. Am. Soc. Sugar Beet Technol. 19:4-15.

Li, H. X., and Brewer, M. T. 2016. Spatial genetic structure and population dynamics of gummy stem blight fungi within and among watermelon fields in the southeastern United States. Phytopathology 106:900-908.

Liang, J. F., Xu, J., and Yang, Z. L. 2009. Divergence, dispersal and recombination in Lepiota cristata from China. Fung. Div. 38:105-124.

Ludwig, J. A., and Reynolds, J. F. 1988. Statistical Ecology: A Primer on Methods and Computing. John Wiley \& Sons, New York.

Mangan, A. 1971. New method for the detection of Pleospora bjoerlingii infection of sugar beet seed. Trans. Br. Mycol. Soc. 57:169-172.

Mangiafico, S. S. 2015. An R Companion for the Handbook of Biological Statistics, Version 1.3.2 i. Rutgers Cooperative Extension, New Brunswick, NJ.

Maude, R. B., Vizor, A. S., and Shuring, C. G. 1969. The control of fungal seed borne diseases by means of a thiram seed soak. Ann. Appl. Biol. 64:245-257.

McDonald, B. A. 2015. How can research on pathogen population biology suggest disease management strategies? The example of barley scald (Rynchosporium commune). Plant Pathol. 64:1005-1013.

McDonald, B. A., and Linde, C. 2002. Pathogen population genetics, evolutionary potential, and durable resistance. Annu. Rev. Phytopathol. 40:349-379.
McDonald, B. A., and Mundt, C. C. 2016. How knowledge of pathogen population biology informs management of Septoria tritici blotch. Phytopathology 106: 948-955.

Meirmans, P. G., and Van Tienderen, P. H. 2004. GENOTYPE and GENODIVE: Two programs for the analysis of genetic diversity of asexual organisms. Mol. Ecol. Notes 4:792-794.

Milgroom, M. G. 1996. Recombination and the multilocus structure of fungal populations. Annu. Rev. Phytopathol. 34:457-477.

Milgroom, M. G. 2001. The synthesis of genetics and epidemiology: Contributions of population biology in plant pathology. J. Plant Pathol. 83:57-62.

Milgroom, M. G., del Mar Jiménez-Gasco, M., García, C. O., Drott, M. T., and Jiménez-Díaz, R. M. 2014. Recombination between clonal lineages of the asexual fungus Verticillium dahliae detected by genotyping by sequencing. PLoS One 9:e106740.

Milgroom, M. G. 2015. Population Biology of Plant Pathogens: Genetics, Ecology, and Evolution. American Phytopathological Society Press, St. Paul, MN.

Miller, P. M. 1955. V-8 juice agar as a general purpose medium for fungi and bacteria. Phytopathology 45:461-462.

Monte, E., and García-Acha, I. 1988. Vegetative and reproductive structures of Phoma betae in vitro. Trans. Br. Mycol. Soc. 90:233-245.

Muzhinji, N., Woodhall, J. W., Truter, M., and van der Waals, J. E. 2018 Relative contribution of seed tuber- and soilborne inoculum to potato disease development and changes in the population genetic structure of Rhizoctonia solani AG 3-PT under field conditions in South Africa. Plant Dis. 102:60-66.

Nei, M. 1972. Genetic distance between populations. Am. Nat. 106:283-292.

Nei, M. 1978. Estimation of average heterozygosity and genetic distance from a small number of individuals. Genetics 89:583-590.

Peakall, R., and Smouse, P. E. 2006. GenAlEx 6: Genetic analysis in Excel. Population genetic software for teaching and research. Mol. Ecol. Notes 6:288-295.

Peakall, R., and Smouse, P. E. 2012. GenAlEx 6.5: Genetic analysis in Excel. Population genetic software for teaching and research-an update. Bioinformatics 28:2537-2539.

Pethybridge, S. J., Kikkert, J. R., Hanson, L. E., and Nelson, S. C. 2018 Challenges and prospects for building resilient disease management strategies and tactics for the New York table beet industry. Agronomy (Basel) 8:112.

Pethybridge, S. J., Vaghefi, N., and Kikkert, J. R. 2017. Horticultural characteristics and susceptibility of table beet cultivars to Cercospora leaf spot in New York. HortTechnol. 27:530-538.

Pompanon, F., Bonin, A., Bellemain, E., and Taberlet, P. 2005. Genotyping errors: Causes, consequences and solutions. Nat. Rev. Genet. 6:847-859.

Pool, V. W., and McKay, M. B. 1915. Phoma betae on the leaves of sugar beet. J. Agric. Res. 4:169-177.

Pritchard, J. K., Stephens, M., and Donnelly, P. 2000. Inference of population structure using multilocus genotype data. Genetics 155:945-959.

R Core Team. 2017. R: A Language and Environment for Statistical Computing. R Foundation for Statistical Computing, Vienna, Austria.

Romero Luna, M. P., Aime, M. C., Chilvers, M. I., and Wise, K. A. 2017. Genetic diversity of Stenocarpella maydis in the major corn production areas of the United States. Plant Dis. 101:2020-2026.

Short, D. P. G., Gurung, S., Hu, X., Inderbitzin, P., and Suubarao, K. V. 2014 Maintenance of sex-related genes and the co-occurrence of both mating types in Verticillium dahliae. PLoS One 9:e112145.

Simpson, E. H. 1949. Measurement of diversity. Nature 163:688.

Solovyev, V. V. 2007. Statistical approaches in Eukaryotic gene prediction. Pages 97-159 in Handbook of Statistical Genetics, D. J. Balding, M. Bishop, and C. Cannings, eds. John Wiley \& Sons, Ltd., West Sussex, UK.

Stivers, L. 2001. Crop profile: Beets in New York. U.S. Department of Pest Management Centers. http://pmep.cce.cornell.edu/fapa/crop-profiles/beet.htm

Taylor, J. W., Jacobson, D. J., and Fisher, M. C. 1999. The evolution of asexual fungi: Reproduction, speciation and classification. Annu. Rev. Phytopathol 37:197-246.

Untergasser, A., Cutcutache, I., Koressaar, T., Ye, J., Faircloth, B. C., Remm, M., and Rozen, S. G. 2012. Primer3-new capabilities and interfaces. Nucleic Acids Res. 40:e115.

U.S. Department of Agriculture National Agricultural Statistics Service. 2012 USDA NASS Quick Stats. https://www.nass.usda.gov/Quick_Stats/

Vaghefi, N., Kikkert, J. R., Bolton, M. D., Hanson, L. E., Secor, G. A., and Pethybridge, S. J. 2017a. De novo genome assembly of Cercospora beticola for microsatellite marker development and validation. Fungal Ecol. 26:125-134

Vaghefi, N., Nelson, S. C., Kikkert, J. R., and Pethybridge, S. J. 2017b. Genetic structure of Cercospora beticola populations on Beta vulgaris in New York and Hawaii. Sci. Rep. 7:1726.

Winter, D. J. 2012. MMOD: An R library for the calculation of population differentiation statistics. Mol. Ecol. Resour. 12:1158-1160.

Zeyl, C., and Bell, G. 1997. The advantage of sex in evolving yeast populations Nature 388:465-468.

Zhan, J., Kema, G. H. J., Waalwijk, C., and McDonald, B. A. 2002. Distribution of mating type alleles in the wheat pathogen Mycosphaerella graminicola over spatial scales from lesions to continents. Fungal Genet. Biol. 36:128-136.

Zhan, J., and McDonald, B. A. 2013. Field-based experimental evolution of three cereal pathogens using a mark-release-recapture strategy. Plant Pathol. 62: $106-114$. 